\title{
Gluten viscoelasticity: Rapid method for classification of soft-like wheat genotypes
}

\author{
Thiago Montagner Souza ${ }^{1}$ (D) | Martha Zavariz de Miranda $^{2}$ | Andre Mateus Prando $^{3}$ | \\ Michael Tilley $^{4}$ | Mark E. Payton ${ }^{5}$ | Patricia Rayas-Duarte ${ }^{6}$ (D)
}

${ }^{1}$ Robert M. Kerr Food \& Agricultural Products Center, Oklahoma State University, Stillwater, Oklahoma

${ }^{2}$ EMBRAPA-Trigo, Passo Fundo, Brazil

${ }^{3}$ EMBRAPA-Soja, Londrina, Brazil

${ }^{4}$ USDA-ARS, CGAHR, Manhattan, Kansas

${ }^{5}$ Department of Statistics, Oklahoma State

University, Stillwater, Oklahoma

${ }^{6}$ Robert M. Kerr Food \& Agricultural

Products Center, Department

of Biochemistry and Molecular

Biology, Oklahoma State University,

Stillwater, Oklahoma

\section{Correspondence}

Patricia Rayas-Duarte, Robert M. Kerr Food \& Agricultural Products Center, Department of Biochemistry and Molecular Biology, Oklahoma State University, Stillwater, OK.

Email: pat.rayas_duarte@okstate.edu

\section{Present address}

Thiago Montagner Souza, Department of Agronomy, Universidade Estadual de Londrina, Londrina, Brazil

Funding information

National Council for Scientific and

Technological Development (CNPq), Grant/ Award Number: 246363

\begin{abstract}
Background and objectives: Standard empirical methods to assess wheat quality are difficult to perform, interpret, time consuming and require a large amount of sample. A rapid uniaxial compression instrument based on measuring height of gluten during compression and recovery is reported. The objective of this study was to determine in a set of soft-like wheat genotypes from Brazil the best conditions to extract the gluten and analyze the efficiency of the method separating categories based on gluten viscoelastic properties. Findings: The independent variables evaluated were as follows: (a) technological quality categories and gluten extraction method; (b) amount of $2 \% \mathrm{NaCl}$ solution (w/v) added for dough formation; (c) mixing time; and (d) washing time. The results were submitted to analysis of variance and means compared by protected LSD test $(p<0.05)$. The best conditions for gluten extraction and analysis were obtained with $4.4 \mathrm{ml}$ of $2 \% \mathrm{NaCl}$ solution, mixing for $20 \mathrm{~s}$, and washing for $3 \mathrm{~min}$. Elastic recovery of gluten showed a strong correlation $(r)$ with standard methods used to classify wheat (dough strength $r=0.988$, stability $r=0.963$ ).

Conclusions: The elastic recovery was able to separate the gluten samples in three categories efficiently and may be a useful tool in breeding programs and flour mills quality control.

Significance and novelty: A novel method for determining elastic recovery of gluten from soft-type wheat genotypes was developed. The set of samples had high correlation of gluten elastic recovery with key quality parameters. Advantages of the test include rapid analysis time (less than $5 \mathrm{~min}$ ) and small sample size (10 $\mathrm{g}$ of flour).
\end{abstract}

\section{K E Y W O R D S}

elastic recovery, flour quality, gluten, rheology, technological properties

\section{1 | INTRODUCTION}

Defined by several characteristics, the term flour quality has different meanings depending on the designation of

Names are necessary to report factually on available data; however, the U.S. Department of Agriculture neither guarantees nor warrants the standard of the product, and use of the name by the U.S. Department of Agriculture implies no approval of the product to the exclusion of others that may also be suitable. use or type of product. The term technological quality of wheat generally indicates the performance of a wheat cultivar and its suitability in the preparation of an enduse product. There are differences in the established wheat quality standards in different countries, classifying wheat according to key quality attributes depending on the point of the production chain (producer, elevator, miller, and processing/characteristics of final products); 
the parameters used may not be the same or differ in importance (Pagani, Marti, \& Bottega, 2014).

Among the methods used to test wheat quality in breeding programs and baking industries are empirical and fundamental rheological tests (large and small deformations, respectively). However, the methods are often time consuming, and some require a large amount of sample and specific training for execution (Chapman, Mulvaney, Chinnaswamy, Rayas-Duarte, $\&$ Allvin, 2012). Around the world, wheat-producing countries have developed their own classification systems based on technological characteristics that can include subclasses with specific targeted end-use functionality in mind, such as "Bread wheat class" (Brazil), "Noodle wheat class" (Australia), and "Pastry wheat class" (India) (Carson \& Edwards, 2009).

Year-to-year variation in wheat quality traits with the new crop is a constant challenge in the milling and baking industry. Wheat breeders reduce the variation of the overall end-use quality traits of cultivars through evaluation and selection. Gluten protein is the major and most crucial component of dough associated directly with bread quality (Marchetti, Cardós, Campaña, \& Ferrero, 2012). Gluten and dough are viscoelastic materials exhibiting properties of solid (cohesion and elasticity) and liquid (viscous or irrecoverable deformation) (Kieffer, 2006; Wieser, 2007). Bakers monitor dough viscoelasticity constantly using empirical methods while mills monitor their blends with laboratory methods including baking the final products.

A rapid uniaxial compression method was developed to test gluten elastic recovery using a Gluten CORE Analyzer (Perten Instruments AB, Huddinge, Sweden). The main advantages of this testing system are the instrument's small sample size, sensitive load cell, and one-minute test time (Chapman et al., 2012). Samples are centrifuged using a specially designed cassette that fits the Perten Glutomatic centrifuge obtaining a cylindrical-shaped sample that is placed into the lower plate of the testing device prior to uniaxial compression, thus reducing handling of the sample. The information provided is closely related to the strain gluten undergoes during gas bubble expansion (Chapman et al., 2012). The Gluten CORE was used to analyze US hard and soft wheat types (Chapman et al., 2012). The instrument software allows the flexibility to adapt to the separation of other wheat types. Brazilian wheat (soft-like genotypes) has a viscous and sticky textured gluten and requires a specific method to separate cultivars based on their viscoelastic properties. There is a need for an efficient method to evaluate rheological characteristics of gluten from Brazilian wheat genotypes, which may help to identify wheat for specific uses. Moreover, the measurement of viscoelastic properties by a method that requires a reduced amount of sample (10 g) compared to standard methods (more than $200 \mathrm{~g}$ ) may be useful in a number of important applications ranging from breeding programs to quality control at flour mills.
This work presents progress toward the development of a rapid gluten test and provides further insight into the behavior of soft-type gluten under uniaxial compression. The objectives of this study were: (a) to determine the best conditions for extraction of gluten from three commercial classes of Brazilian wheat genotypes (Improver, Bread, and Basic classes); (b) to determine the compression-recovery behavior of gluten; and (c) to investigate possible correlation of the elastic recovery obtained compared to standard empirical methods used in Brazil to classify wheat according to its technological quality.

\section{2 | MATERIAL AND METHODS}

\section{1 | Wheat samples}

The study was divided into two parts using two different sets of samples. In the first part, three Brazilian wheat genotypes representing three different commercial samples classified according to technological properties were selected for studying the best extraction conditions for gluten and separation of their elastic recovery properties with a compression and recovery test. These genotypes represented Basic (WT 09021), Bread (BRS Gaivota), and Improver (BRS Pardela) classes, according to the commercial classification of Brazilian wheat (Bassoi et al., 2017; MAPA, 2010). In the second part of the study, a second set of samples, consisted of 44 samples from 12 Brazilian wheat genotypes grown in two locations with distinct weather conditions (South and Southeast region), were analyzed with the selected method from the first part and used as a preliminary validation test (Table 1).

\section{$2.2 \quad$ Location and characterization of experimental area}

The first set of samples were three selected wheat genotypes (experimental line WT 09021 and cultivars BRS Gaivota and BRS Pardela) grown in experimental plots in the District of Warta, Londrina, Paraná, Brazil, in 2013. The District of Warta (Londrina) is located $23^{\circ} 11^{\prime}$ south latitude, $51^{\circ} 10^{\prime}$ west longitude, with an altitude average of $605 \mathrm{~m}$. The soil of the site is characterized as distroferric red latosol. According to the classification of Köppen, the climate is humid subtropical (Cfa): average temperature in the coldest month below $18^{\circ} \mathrm{C}$ (mesothermic) and average temperature in the warmer month above $22^{\circ} \mathrm{C}$, with hot summers, infrequent frost and tendency of rainfall concentration in the summer months, but without defined dry season.

The first location where part of the second set of samples were grown is at the experimental plots at Pato Branco, Paraná, Brazil, in 2013. The area is located at $26^{\circ} 07^{\prime}$ south latitude, $52^{\circ} 41^{\prime}$ west longitude, with an altitude average 
TA B LE 1 List of Brazilian wheat genotypes and number of samples grown in two locations with different climatic conditions

\begin{tabular}{|c|c|c|c|}
\hline \multirow[b]{2}{*}{ Genotypes } & \multicolumn{2}{|c|}{ Growth location } & \multirow[b]{2}{*}{$\begin{array}{l}\text { Total observations } \\
\text { per cultivar }\end{array}$} \\
\hline & $\begin{array}{l}\text { Pato Branco }^{a} \\
\text { Parana/Brazil }\end{array}$ & $\begin{array}{l}\text { Ponta Grossa }^{\text {b }} \\
\text { Parana/Brazil }\end{array}$ & \\
\hline BRS Gralha Azul & 1 & 2 & 3 \\
\hline BRS Pardela & 2 & 2 & 4 \\
\hline WT 08111 & 2 & 2 & 4 \\
\hline WT 10008 & 2 & 2 & 4 \\
\hline WT 10014 & 2 & 2 & 4 \\
\hline WT 11035 & 2 & 2 & 4 \\
\hline WT 11107 & 1 & 2 & 3 \\
\hline WT 11110 & 2 & 1 & 3 \\
\hline WT 11118 & 1 & 2 & 3 \\
\hline WT 11139 & 2 & 2 & 4 \\
\hline WT 11155 & 2 & 2 & 4 \\
\hline WT 11167 & 2 & 2 & 4 \\
\hline $\begin{array}{l}\text { Total observations per } \\
\text { location }\end{array}$ & 21 & 23 & 44 \\
\hline
\end{tabular}

of $700 \mathrm{~m}$. The soil of the site is characterized as oxisol. According to the classification of Köppen, the climate is also classified as humid subtropical (Cfa). The second location was at Ponta Grossa, Paraná, Brazil, in 2013. The area is located at $25^{\circ} 09^{\prime}$ south latitude, $50^{\circ} 06^{\prime}$ west longitude, with an altitude average of $800 \mathrm{~m}$. The soil of the site is characterized as distroferric red latosol. According to the classification of Köppen, the climate is temperate $(\mathrm{Cfb})$ : temperature in the coldest month below $18^{\circ} \mathrm{C}$ (mesothermic), with fresh summers, average temperature in the hottest month below $22^{\circ} \mathrm{C}$ and no defined dry season.

\section{3 $\mid$ Flour extraction}

Wheat kernels were cleaned and tempered to $14 \%$ moisture for approximately $16 \mathrm{hr}$ prior to milling using a roller mill (Quadrumat Junior ${ }^{\circledR}$, Brabender, Duisburg, Germany) according to AACC International Approved Method 26-10.02. Flour was obtained by mixing the break and reduction flours. Flours were packed in polyethylene bags and stored at $-4^{\circ} \mathrm{C}$ until further analysis.

\section{4 | Experimental design of gluten extraction method}

The key variables that affect the method for gluten extraction were investigated. Independent variables evaluated were as follows: (a) market classification of Brazilian wheat genotypes (Improver, Bread, or Basic); (b) initial amount of $2 \%$ $\mathrm{NaCl}$ solution (w/v) added to hydrate the flour sample before mixing $(4.0,4.4$, or $4.8 \mathrm{ml})$; (c) mixing time of the dough before washing step (20 or $30 \mathrm{~s}$ ); and (d) washing time of the dough $(3,4$, or $5 \mathrm{~min})$ during the extraction of gluten. The experiment was designed in randomized blocks (five blocks), in a factorial structure of 3 (genotypes) $\times 3$ (amount of $2 \%$ $\mathrm{NaCl}$ solution $) \times 2$ (mixing time) $\times 3$ (washing time) with a total of 54 treatments.

\section{5 | Protein content and rheological properties of samples}

Protein content was determined by NIR spectroscopy (MOD XDS-Rapid Content Analyzer, FOSS NIRSystems ${ }^{\circledR}$, Hoganas, Sweden), with double detection system (model 6500 monochromator with measuring range: silicon 400$1,100 \mathrm{~nm}$ and lead sulfide $1,100-2,500 \mathrm{~nm}$ ), and equipped with ISIScanTM software (Infrasoft International LLC, State College, PA, USA). Analyses were done in triplicate.

Technological analyses were performed following AACCI Approved Methods for alveograph (54-30.02), farinograph (54-21.02), and falling number (56-81.03). Alveograph and farinograph determined large deformation rheological properties and falling number the soundness of wheat (sprout damage). Analyses were done in triplicate.

\section{6 | Protein characterization}

For the analysis of high molecular weight-glutenin subunit (HMW-GS) composition, $100 \mathrm{mg}$ flour was suspended in $1 \mathrm{ml}$ of $0.3 \mathrm{M}$ sodium iodide containing $7.5 \%$ 1-propanol, vortexed for $15 \mathrm{~min}$, centrifuged at $12,000 \times g$ for $5 \mathrm{~min}$, and the supernatant was discarded. The pellet was washed with water for 
$5 \mathrm{~min}$ and centrifuged for $5 \mathrm{~min}$ at $12,000 \times \mathrm{g}$. Glutenins in the pellet were extracted in $1 \mathrm{ml}$ of 50\% 1-propanol containing $2 \%(\mathrm{w} / \mathrm{v}, \mathrm{g} / 100 \mathrm{ml}$ ) of sodium dodecyl sulfate (SDS) and 2\% $(\mathrm{v} / \mathrm{v}, \mathrm{ml} / 100 \mathrm{ml})$ of 2-mercaptoethanol (BME) by vortex shaking for $30 \mathrm{~min}$ (Fu \& Kovacs, 1999). The solution was centrifuged for $5 \mathrm{~min}$ at $12,000 \times \mathrm{g}$, the supernatant was collected, and HMW-GS were identified by Lab-on-a-Chip electrophoresis method using an Agilent 2100 Bioanalyzer following the Protein 230 chip kit protocol (Agilent Technologies, Palo Alto, CA, US). The numbering of HMW-GS alleles at the Glu$A 1$, Glu-Bl, and Glu-Dl loci was based upon the classification system of Payne and Lawrence (1983). Wheat cultivar standards were cv. Chinese Spring (null, 7+8, 2+12), cv. Karl-92 $(1,7+8,5+10)$, and cv. Jagger $(1,17+18,5+10)$.

Samples with high levels of subunit Glu-B1 7 were confirmed at the genetic level using the polymerase chain reaction (PCR). DNA was extracted from flour using the DNeasy Mericon Food Kit (Qiagen, Germantown, MD, USA), and PCR analysis was performed using primers and conditions described by Butow et al. (2004). Following amplification, products were analyzed using an Agilent 2100 Bioanalyzer and DNA 1000 kit. Using the Canadian cultivar Glenlea as a positive control, samples were assessed for the presence of a $43 \mathrm{bp}$ insertion associated with overexpression of Glu-1 Bx7 $\left(\mathrm{Bx} 7^{\mathrm{oe}}\right)$.

Presence of wheat-rye translocation was initially examined using SDS-PAGE according to the method described by Tabibzadeh, Karimzadeh, and Naghavi (2013). PCR was also used to determine the type of rye translocations using primers TSM0120 as described by Abdelsalam (2014). Controls consisted of rye translocation lines TAM 107 (1AL/RS) and Siouxland (1BL/RS). Following amplification, products were analyzed using an Agilent 2100 Bioanalyzer and DNA 1000 kit. The quality score for composition of glutenin subunits was calculated according to Payne, Nightingale, Krattiger, \& Holt (1987). Analyses were done in duplicate.

\subsection{1 | Soluble and insoluble proteins}

The percentage of insoluble polymeric proteins (IPP) was determined as described by Bean, Lyne, Tilley, Chung, and Lookhart (1998). Briefly, $100 \mathrm{mg}$ flour sample was suspended in $1 \mathrm{ml}$ of 50\% 1-propanol, vortex stirred for $5 \mathrm{~min}$, and centrifuged for $5 \mathrm{~min}$ at $12,000 \times \mathrm{g}$. The supernatant was discarded, and the procedure repeated twice. The pellet was lyophilized, and crude protein content was determined with AACCI Approved Method 46.30.01. Insoluble polymeric protein percentage (IPP) was calculated by multiplying nitrogen values by a conversion factor of 5.7 and dividing by total flour protein (AACCI Approved Method 46-19.01). Analyses were done in duplicate.

Quantity and polymeric composition were determined quantitatively using the extraction procedure described by Gupta, Khan, and MacRitchie (1993). Briefly, 20 mg sample was suspended in $1 \mathrm{ml}$ of $0.05 \mathrm{M}$ sodium phosphate buffer, $\mathrm{pH}$ 6.9, containing $0.5 \%$ SDS (w/v), and sonicated for $15 \mathrm{~s}$ at $10 \mathrm{~W}$. The extract was centrifuged for $5 \mathrm{~min}$ at $12,000 \times g$, and the supernatant filtered using a $0.45-\mu \mathrm{m}$ Spin-X nylon centrifuge tube filter. The extract was analyzed by size exclusion chromatography using an Agilent 1100 HPLC (Agilent Technologies, Palo Alto, CA, USA) equipped with a Biosep-SEC-s4000 column $(300 \times 7.8 \mathrm{~mm}$, particle size $5 \mu \mathrm{m}$, pore size $500 \AA$ ) (Phenomenex, Torrance, CA, USA). Protein extract $(20 \mu \mathrm{l})$ was loaded onto the column and eluted with $50 \%$ acetonitrile in water $(\mathrm{v} / \mathrm{v})$, containing $0.05 \%(\mathrm{v} / \mathrm{v})$ of trifluoroacetic acid. The column temperature was $40^{\circ} \mathrm{C}$ with a flow rate of $1.0 \mathrm{ml} / \mathrm{min}$ with a total runtime of $28 \mathrm{~min}$. A variable wavelength detector set to $214 \mathrm{~nm}$ was used, and analysis was performed using the Agilent ChemStation software program. The chromatograms were manually integrated into two main peaks. The area of the first peak corresponds to polymeric proteins and the area of the second peak to monomeric proteins. The ratio of total polymeric protein (TPP) to total monomeric protein (TMP) was recorded and calculated as described by Larroque, Gianibelli, Batey, and MacRitchie (1997) and Gupta et al. (1993). Analyses were done in duplicate.

\subsubsection{Gliadin and high/low molecular weight-glutenin subunits}

Gliadin patterns and HMW/LMW glutenin ratios were determined by reverse-phase-high performance liquid chromatography (RP-HPLC). Briefly, $100 \mathrm{mg}$ of flour was stirred with $1 \mathrm{ml}$ sodium iodate buffer $(0.3 \mathrm{M}$ sodium iodate and $7.5 \%$ isopropanol) (Fu \& Kovacs, 1999) for $15 \mathrm{~min}$ and centrifuged for $5 \mathrm{~min}$ at $17,000 \times \mathrm{g}$. The supernatant was filtered through $0.45 \mu \mathrm{m}$ filter and analyzed as described by Waga et al. (2013). A Jupiter C18 column $(250 \times 4.6 \mathrm{~mm}$, Phenomenex, Torrance, CA, USA) was used. Elution solvents $A$ and $B$ were water containing $0.1 \%$ of trifluoroacetic acid $(\mathrm{v} / \mathrm{v})$ and acetonitrile containing $0.05 \%$ of trifluoroacetic acid $(\mathrm{v} / \mathrm{v})$, respectively. The linear gradient elution was $25 \%$ B to $50 \%$ B for $80 \mathrm{~min}$, flow rate $1 \mathrm{ml} / \mathrm{min}$, column temperature $70^{\circ} \mathrm{C}$, detection at $210 \mathrm{~nm}$, and manual integration of peaks using Agilent ChemStation software. Gliadin peaks were classified into four groups with retention times ranges between: (a) 20-26 min, $\omega$-gliadins; (b) 26-31 min, $\beta$-gliadins; (c) 31-40 min, $\alpha$-gliadins; and (d) 40-60 min, $\gamma$-gliadins. Analyses were done in duplicate.

\section{7 | Gluten preparation and analysis}

For gluten extraction, soluble components of flour were washed with $2 \% \mathrm{NaCl}$ solution $(\mathrm{w} / \mathrm{v})$, one sample at a time. The extraction was performed using a Glutomatic System (Model 2200, Perten Instruments, Huddinge, Stockholm, 
Sweden), based on AACCI Approved Method 38-12.02, with modifications. The settings used for the extraction varied according to the experimental design. A sample of $10 \mathrm{~g}$ of flour was placed in the Glutomatic chamber, and $2 \%$ of $\mathrm{NaCl}$ solution $(4.0,4.4$, or $4.8 \mathrm{ml})$ was added and mixed for 20 or $30 \mathrm{~s}$, according to the treatment. Once the dough ball was formed, starch was washed out with $2 \% \mathrm{NaCl}$ solution through a polyester screen $(88 \mu \mathrm{m})$ for 3,4 , or $5 \mathrm{~min}$. Once the gluten was extracted, the uniaxial compression test was performed as described by Chapman et al. (2012) with modifications for soft-type gluten. The gluten was centrifuged for $1 \mathrm{~min}$, using a dummy gluten sample to balance the centrifuge, in order to shape the sample into a cylindrical form for analysis. The conditions of the test were sampling rate $100 \mathrm{~ms}$, target force $0.5 \mathrm{~N}$, hold time start $0 \mathrm{~s}$, velocity start $20 \mathrm{~mm} / \mathrm{s}$, target force compression $3 \mathrm{~N}$, minimum distance $1 \mathrm{~mm}$, target force recovery $0.2 \mathrm{~N}$, recovery time $55 \mathrm{~s}$, and velocity compression $4 \mathrm{~mm} / \mathrm{s}$. The Gluten CORE analyzer recorded the height of the gluten as a function of time (Figure 1). At least five replicates for each cultivar were obtained from independently washed flour samples. A light layer of mineral oil was applied to the plates to avoid stickiness. After completing the compression-recovery test, the gluten sample was weighed and dried to estimate the wet and dry gluten content, expressed in $14 \%$ moisture basis, and water binding capacity of the samples as described by AACCI Approved Method 38-12.02.

\section{8 $\quad$ Statistical analysis}

Data were subjected to analysis of variance (ANOVA) using SAS version 9.4 (SAS Institute, Cary, NC, USA) to assess the effect of the initial amount of $2 \% \mathrm{NaCl}$ solution, mixing and washing time of the dough on the extraction of gluten from wheat genotypes from different commercial classes. Mean comparison was performed by protected least significant difference test (LSD), and Pearson's correlation was performed between the proposed compression and recovery test and the standard methods used in Brazil to classify wheat according to its technological quality.

\section{RESULTS AND DISCUSSION}

\section{1 | Physicochemical and rheological characterization}

The values of protein and traditional rheological properties of the three selected Brazilian wheat genotypes are reported in Table 2. In Brazil, wheat and flour protein contents are expressed as dry basis $(0 \% \mathrm{mb})$, thus the protein values are presented as both dry basis and 14\% moisture basis (Table 2). The ranking by protein content was WT $09021=$ BRS Pardela (average $14.1 \% \mathrm{db} / 12.1 \%)<$ BRS Gaivota $(14.7 \% \mathrm{db} / 12.6 \%)(p<0.05)$. These protein levels are comparable to the high tier values of the

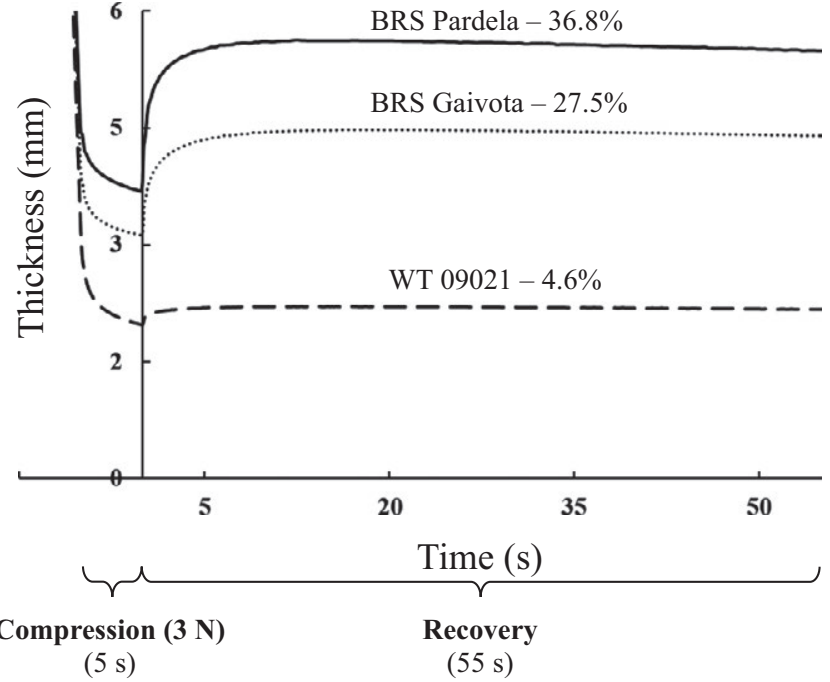

F IG URE 1 Compression-recovery curves of gluten from three Brazilian wheat genotypes obtained with a Gluten CORE Analyzer, representing three classes: Basic, WT 090211; Bread, BRS Gaivota; and Improver, BRS Pardela. Mean elastic recovery $\%$ after each cultivar name. Gluten extraction method: $4.4 \mathrm{ml}$ of $2 \%$ salt solution, 20 s mixing, and 3 min washing

2017 crop of hard red winter wheat (14.1\% dry basis) from the United States (US Wheat Associates, 2017). Quantitative characteristics are expressed by a large number of genes, which can be strongly influenced by the environment. Protein content may vary significantly depending on the environmental conditions (climate, soil, etc.) in which the grain is cultivated, as well as on genetic diversity (Panozzo \& Eagles, 2000).

A normative instruction from the Brazilian Ministry of Agriculture, Livestock and Food Supply is used as a reference to classify wheat cultivars based on dough strength (alveograph), stability (farinograph), and falling number into five classes: Improver; Bread; Domestic; Basic; and Other Uses (MAPA, 2010). For example, minimum values established for dough strength ( $\geq 300 \mathrm{~W})$, stability ( $\geq 14 \mathrm{~min})$, and falling number ( $\geq 250 \mathrm{~s})$ need to be met for a wheat cultivar to be classified as Improver (MAPA, 2010). The three cultivars selected in the first part of this study presented characteristics according to their class, except for BRS Pardela (Improver) with dough stability lower than the minimum norm requirement ( 8 min vs. $14 \mathrm{~min}$ ). Overall, the value is within the observed variation on Rio Grande do Sul and Paraná State, the main wheat-producing states in Brazil which has higher variation in key flour characteristics compared to other adaptive regions in the country (Castro et al., 2016).

\section{2 | Protein characterization}

Parameters of protein characterization of the three samples including HMW-GS composition, glutenin/gliadin ratio, and gliadin composition of the wheat genotypes are reported in 
TA B L E 2 Protein content and traditional rheological properties of Brazilian wheat genotypes representative of Basic, Bread, and Improver classes in Brazil ${ }^{\mathrm{a}}$

\begin{tabular}{|c|c|c|c|c|}
\hline $\begin{array}{l}\text { Genotypes } \\
\text { Brazilian Wheat Class }\end{array}$ & & $\begin{array}{l}\text { WT } 09021 \\
\text { Basic }\end{array}$ & $\begin{array}{l}\text { BRS Gaivota } \\
\text { Bread }\end{array}$ & $\begin{array}{l}\text { BRS Pardela } \\
\text { Improver }\end{array}$ \\
\hline \multirow[t]{3}{*}{ Alveograph } & Protein $(\%)^{\mathrm{b}}$ & $12.6 / 14.2 \pm 0.1 b$ & $12.2 / 14.7 \pm 0.2 \mathrm{a}$ & $12.0 / 13.9 \pm 0.1 b$ \\
\hline & Tenacity $(\mathrm{P}, \mathrm{mm})$ & $54.0 \pm 1.0 \mathrm{c}$ & $67.0 \pm 0.0 \mathrm{~b}$ & $84.0 \pm 1.0 \mathrm{a}$ \\
\hline & Extensibility (L, mm) & $180 \pm 1.0 \mathrm{a}$ & $150 \pm 0.0 \mathrm{~b}$ & $167 \pm 1.0 \mathrm{c}$ \\
\hline \multirow[t]{4}{*}{ Farinograph } & Peak time (min) & $4.1 \pm 0.1 b$ & $6.7 \pm 0.9 a$ & $6.4 \pm 0.1 \mathrm{a}$ \\
\hline & Stability $(\min )$ & $2.70 \pm 0.1 b$ & $5.2 \pm 0.9 b$ & $8.0 \pm 0.7 \mathrm{a}$ \\
\hline & Mixing tolerance index (UF) & $71.0 \pm 9.0 \mathrm{a}$ & $42.0 \pm 11.0 \mathrm{ab}$ & $23.0 \pm 2.0 \mathrm{~b}$ \\
\hline & Falling number $(\mathrm{s})$ & $431 \pm 8.0 b$ & $566 \pm 3.0 \mathrm{a}$ & $399 \pm 1.0 \mathrm{c}$ \\
\hline
\end{tabular}

${ }^{\mathrm{a}}$ Means ( $n=3 \pm$ standard deviation) within a row followed by the same letter are not significantly different $(p>0.05)$. ${ }^{\mathrm{b}}$ Protein content, $14 \% / 0 \%$ moisture basis.

T A B L E 3 Protein characterization of three Brazilian wheat genotypes analyzed for high molecular weight-glutenin subunit composition of locus $G l u-A 1, G l u-B 1$, and $G l u-D 1$, Glu-1 quality score, total polymeric to monomeric protein ratio, insoluble polymeric protein and ratio of low to high molecular weight-glutenin subunits and gliadin class composition ${ }^{\mathrm{a}}$

\begin{tabular}{|c|c|c|c|c|}
\hline $\begin{array}{l}\text { Genotypes } \\
\text { Brazilian Wheat Class }\end{array}$ & & $\begin{array}{l}\text { WT } 09021 \\
\text { Basic }\end{array}$ & $\begin{array}{l}\text { BRS Gaivota } \\
\text { Bread }\end{array}$ & $\begin{array}{l}\text { BRS Pardela } \\
\text { Improver }\end{array}$ \\
\hline \multirow[t]{5}{*}{ Glutenin subunits } & Glu-A1 & 1 & $2 *$ & $2 *$ \\
\hline & Glu-D1 & $2+12$ & $2+12$ & $5+10$ \\
\hline & Glu-1 Quality Score ${ }^{b}$ & 8 & 5 & 10 \\
\hline & $\operatorname{IPP}(\%)^{\mathrm{d}}$ & $39.6 \pm 1.9 \mathrm{~b}$ & $43.3 \pm 1.3 \mathrm{ab}$ & $45.9 \pm 3.3 \mathrm{a}$ \\
\hline & LMW-GS/HMW-GS & $2.6 \pm 0.0 \mathrm{a}$ & $1.6 \pm 0.1 \mathrm{c}$ & $2.1 \pm 0.0 \mathrm{~b}$ \\
\hline \multirow[t]{2}{*}{ Gliadin class $(\%)$} & $\omega$-Gliadins & $16.6 \pm 0.3 b$ & $19.2 \pm 0.3 \mathrm{a}$ & $17.0 \pm 0.4 b$ \\
\hline & $\alpha / \beta$-Gliadins & $35.3 \pm 0.2 \mathrm{a}$ & $34.9 \pm 0.4 \mathrm{a}$ & $33.7 \pm 0.1 b$ \\
\hline
\end{tabular}

${ }^{\mathrm{a}}$ Means $\left(n=2 \pm\right.$ standard deviation) within a row followed by the same letter are not significantly different $(p>0.05)$. ${ }^{\mathrm{b}}$ Glu- 1 Quality Score calculated as per Payne et al. (1987). ${ }^{\mathrm{c}} \mathrm{TPP} / \mathrm{TMP}=$ Total polymeric to total monomeric protein ratio. ${ }^{\mathrm{d}} \mathrm{IPP}(\%)=$ Percentage of insoluble polymeric protein. ${ }^{\mathrm{e}} \mathrm{Ratio}$ of low to high molecular weight-glutenin subunits.

Table 3. Only the Improver sample (BRS Pardela) had the Glu-D1 subunits 5+10 while the Basic (WT 09021) and Bread (BRS Gaivota) had HMW-GS 2+12 at Glu-D1. Cultivar BRS Gaivota has overexpressed $\mathrm{Bx} 7$ subunit $\left(7^{\mathrm{OE}}+8\right)$ (Figure 2) and rye translocation 1BL/1R (Figure 3). Rye translocations were identified by the presence of an amplification product of 382 bp (1AL/1RS) or 372 bp (1BL/1RS) using the molecular markers and positive controls TAM 107(1AL/1RS) and Siouxland (1BL/1RS). No amplification was observed in WT 09021 and BRS Pardela (Figure 3).

It is well accepted that the variations in both quantity and quality of glutenin subunits strongly determine the variations in bread-making performance. Studies have shown that dough rheological properties are directly related to the amount and type of HMW-glutenin subunits (Barak, Mudgil, \& Khatkar, 2013; Johansson et al., 2013; Veraverbeke \& Delcour, 2002). Torres et al. (2008) analyzed the HMW-GS profile of 83 wheat genotypes from the Brazilian breeding program observed the following proportions: $G l u-A l=2 *(74.7 \%)>1$ $(16.9 \%)>$ Null $\quad(8.4 \%) ; \quad$ Glu-Bl $=7+9 \quad(47.0 \%)>7+8$ $(26.5 \%)>17+18 \quad(16.9 \%)>13+16 \quad(8.4 \%)>7 \quad(1.2 \%) ;$ GluDl $=5+10(55.4 \%)>2+12(44.6 \%)$. Furthermore, Costa, Scholz, and Franco (2013) evaluating 16 Brazilian wheat cultivars observed that $81.3 \%$ and $18.7 \%$ of the samples presented the subunit $5+10$ and $2+12$, respectively, at the GluD1 locus. 

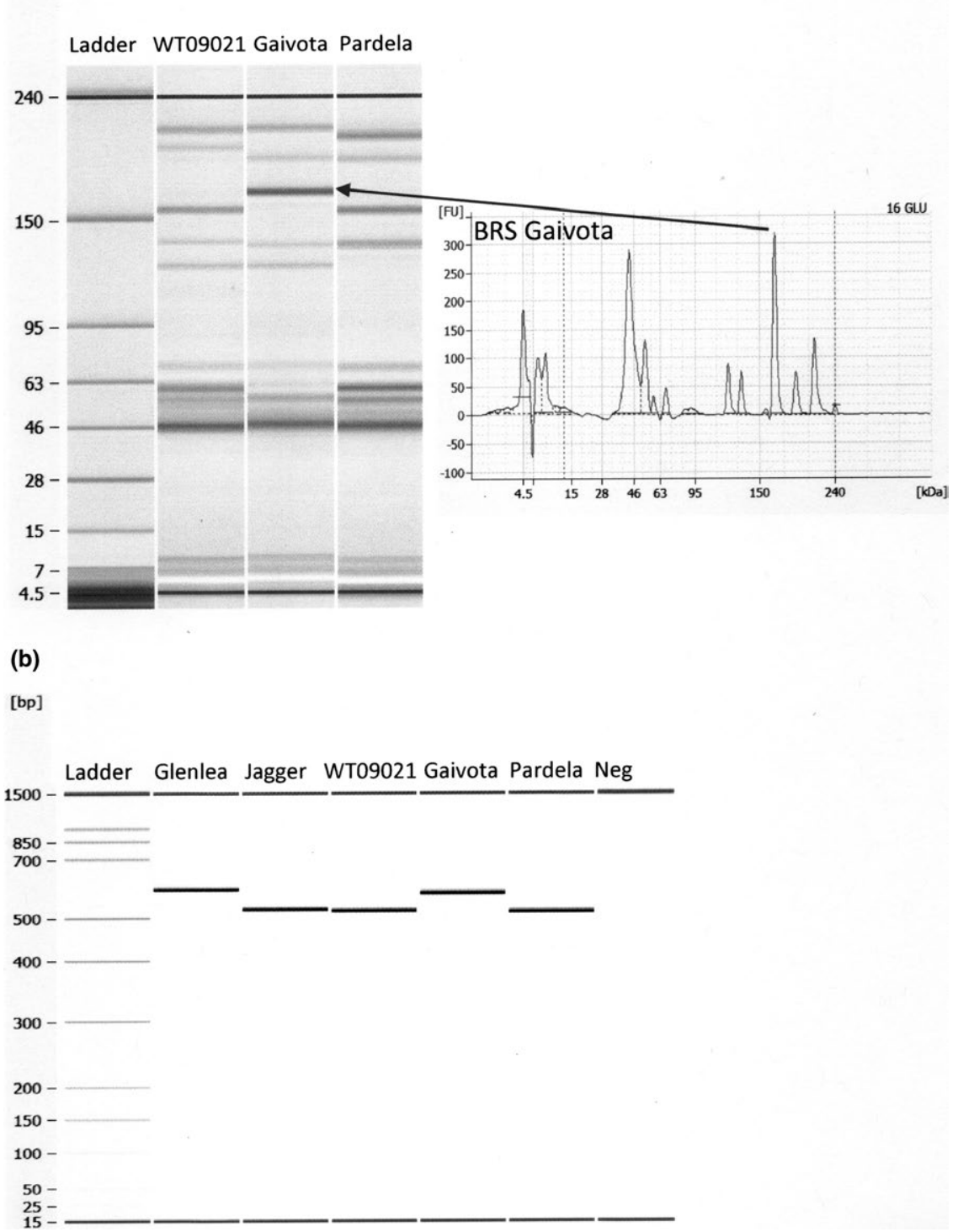

\section{(a)}

[kDa]

(b)

[bp]

\section{)}

F I G U RE 2 (a) Identification of high molecular weight-glutenin subunits (HMWGS) of three soft-type Brazilian wheat genotypes using a Lab-on-a-Chip. (b) Labon-a-Chip separation of PCR products using primer set for overexpression of subunit $\mathrm{Bx} 7$ $\left(7^{\mathrm{OE}}+8\right)$, with Glenlea as positive and Jagger cultivar as negative control
As observed by Barak et al. (2013), the presence of subunit $2 *$ and 5+10 subunits as found in BRS Pardela (Improver class) contributed significantly to improved bread quality of wheat. He, Liu, Xia, Liu, and Pena (2005) studying the effects of the subunits of each locus on gluten quality for bread-making also observed that the combinations $1,7+8$, $5+10$ contribute to improved quality of wheat genotypes. Overall, it has been demonstrated that subunit pair $5+10$ is closely associated with better bread-making quality, whereas $2+12$ is associated with poor bread-making properties.

In wheat, the genes encoding HMW-GS proteins are located at the orthologous loci Glu-A1, Glu-B1, and Glu-D1. Through genetic, breeding, and transgenic studies, the overexpression of certain subunits (i.e., $1 \mathrm{Dx} 5,1 \mathrm{Ax} 1,1 \mathrm{Bx} 7^{\mathrm{OE}}$ ) was correlated with superior bread-making quality (Dong et al., 2010). The basic class sample WT 09021 presented subunits
$2+12$, as did bread class cultivar BRS Gaivota, which also presented the overexpression of subunit $7\left(\mathrm{Bx} 7^{\mathrm{OE}}\right)$, as confirmed in Figure 2. This is a likely explanation for the increased dough strength observed in several parameters in Table 2.

Specific selections of these subunits in conventional and molecular breeding programs have contributed to the genetic improvement of bread-making quality in worldwide wheat production. When the $\mathrm{Bx} 7$ subunit is overexpressed $\left(7^{\mathrm{OE}}+8\right)$ as a percentage of the total amount of HMW-glutenin subunit present, this overexpression is associated with improvement of dough strength (Eagles, Hollamby, Gororo, \& Eastwood, 2002). However, this cultivar also had wheat-rye translocation (1AL/1RS), known to result in detrimental effects such as producing a sticky dough, with inferior dough-mixing properties, and low SDS sedimentation volumes (Carver \& 


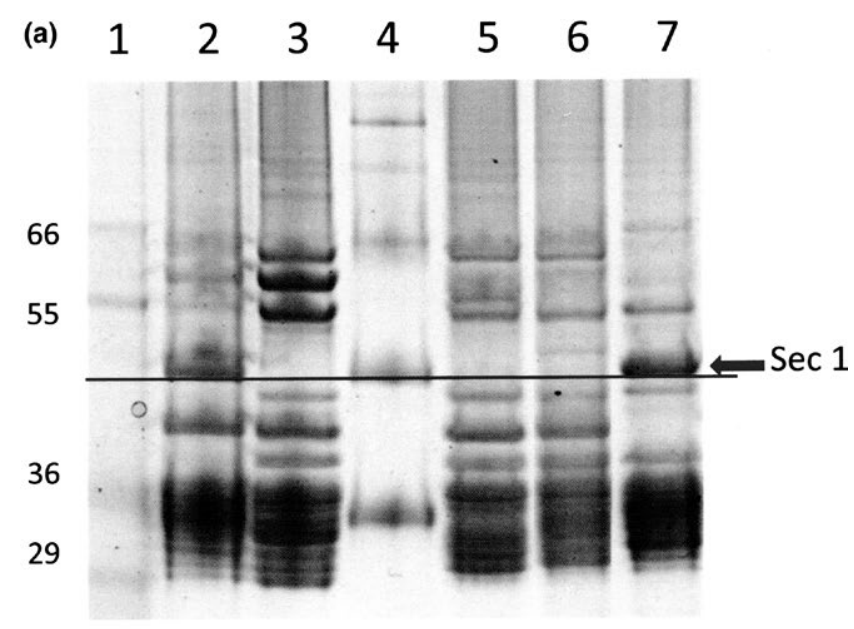

(b)

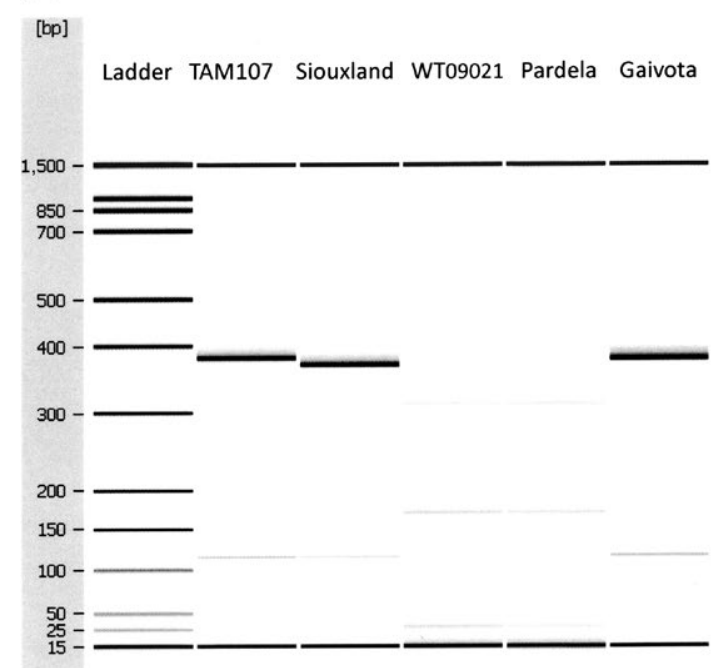

F I G U RE 3 Identification of rye translocation in Brazilian wheats. (a) SDS-PAGE analysis presence of rye secalin: (1) Molecular weight markers, (2) TAM 107 (positive control), (3) Chinese Spring (negative control), (4) Rye flour (positive control), (5) WT 09021, (6) BRS Pardela, and (7) BRS Gaivota. (b) Lab-on-a-Chip separation of PCR products using primer set for: 1AL/RS (Tam 107), 1BL/RS (Siouxland), WT 09021, BRS Pardela, and BRS Gaivota

Rayburn, 1995). These undesirable dough properties are partially caused by the presence of $\omega$-secalins, a family of small monomeric rye proteins (Hussain \& Lukow, 1994). Li et al. (2016) observed that the presence of 1RS arm increased protein, wet gluten and dry gluten content and water absorption, but it decreased gluten index and stability time of the dough, in addition to an increase in dough stickiness. Costa et al. (2013) observed that from 16 Brazilian wheat cultivars evaluated four genotypes (25\%) presented the rye translocation.

The Glu- 1 quality score presented in Table 3 can partially explain the observations made for the technological properties of the cultivars used in this study. The Improver class BRS Pardela had the highest Glu-1 quality score (10) of the three classes, while the lowest score was for the bread class (BRS Gaivota) due to a -3 penalty incurred due to the presence of the rye translocation. However, the quality score needs to be updated to take into account the overexpression of HMWGS $\mathrm{Bx} 7\left(\mathrm{Bx} 7^{\mathrm{OE}}\right)$. The Glu-1 quality score is an important approach to estimate the quality of a genotype based on its allelic composition. More research needs to be done to revise the scoring method to represent overexpression of HMW-GS.

An important characteristic of gluten that determines the mixing time of dough is the size distribution of the gluten proteins. This consideration involves the ratio of monomericto-polymeric proteins, and especially the size distribution of the polymeric proteins. The ratio of polymeric to monomeric proteins, that is, glutenin to gliadin ratio, observed in the three samples indicated a high concentration of monomeric proteins (ratio range 0.66 to 0.84 ), which explains their sticky behavior (Table 3). As known, monomeric gliadins are mostly responsible for the cohesiveness and extensibility characters in the gluten system, whereas polymeric glutenins are responsible for the elasticity and strength of gluten. The ratio of glutenins to gliadins controls the dough strength and extensibility (Khatkar, Fido, Tatham, \& Schofield, 2002; Wrigley, Bekes, \& Bushuk, 2006). Several researchers use glutenin to gliadin ratio to predict bread-making quality and found it to be accurate and reliable. It is desirable to have a stable ratio of glutenin to gliadin for the purpose of good bread-making quality. However, glutenin to gliadin ratio is affected by environmental factors such as heat stress and soil fertility (Zhu \& Khan, 2001) among other factors.

More than $45 \%$ of the gliadin present in the flours was $\gamma$-gliadin, presenting the following concentration order $\gamma$-gliadin (average $47.7 \%$ ) $>\alpha / \beta$-gliadin (average $34.6 \%$ ) > $\omega$-gliadin (average 17.6\%) (Table 3). These observations are in agreement with previous reports finding that $\alpha / \beta$ - and $\gamma$-gliadins are major components, with $\omega$-gliadins occurring in lower proportions (Wieser \& Kieffer, 2001). According to Khatkar et al. (2002), the addition of gliadin and its subgroups to flour changes the mixograph properties increasing the resistance breakdown of the dough (RBD). Within gliadin subgroups, RBD values increased in the sequence $\omega-<\gamma-<\alpha-<\beta$-gliadins. Khatkar and collaborators also pointed out that addition of gliadin subgroups ( $\alpha-, \beta-$, and $\gamma$-gliadins) increased the peak dough resistance of the base flour to a greater extent than gluten and $\omega$-gliadin addition.

\section{3 | Gluten extraction}

Due to the low polymeric to monomeric protein ratios present in the Brazilian wheat genotypes, the wheat was soft with sticky gluten. In order to prevent the clogging of the Glutomatic sieve, the gluten extraction method required adjustments to decrease stickiness of the samples. The method developed by Chapman et al. (2012) was used as guide and the variables such as amount of $2 \% \mathrm{NaCl}$ solution added to 
产
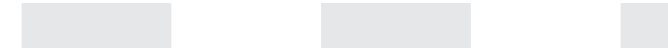

अ ती पु

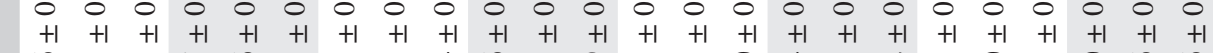

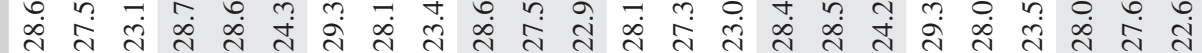

$=$ 궁

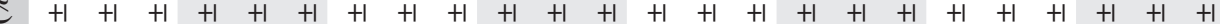

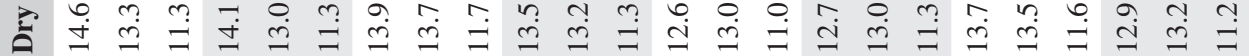

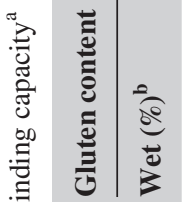

உ

$\begin{array}{lllllllllllllllllllll}0 & 0 & 0 & 0 & 0 & 0 & 0 & 0 & 0 & 0 & 0 & 0 & 0 & 0 & 0 & 0 & 0 & 0 & 0 & 0 & 0\end{array}$

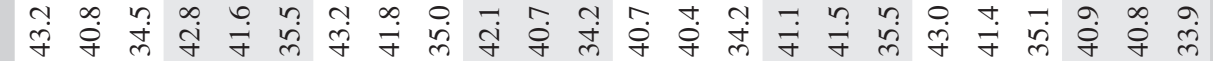

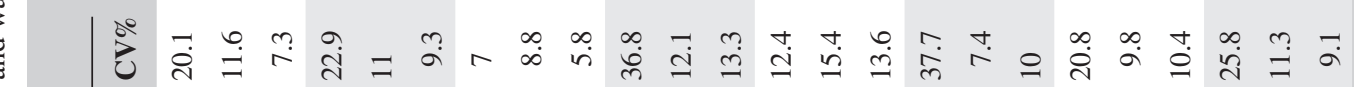

节

离

焉

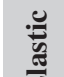

赵

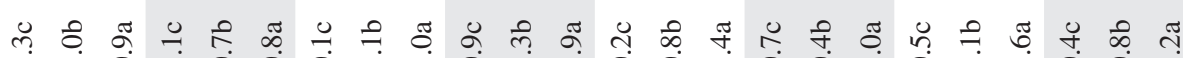

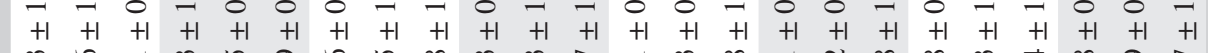

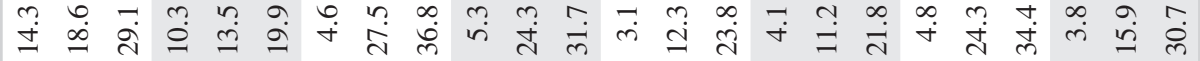

$\stackrel{\overrightarrow{0}}{3}$

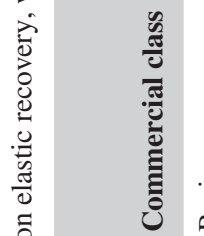

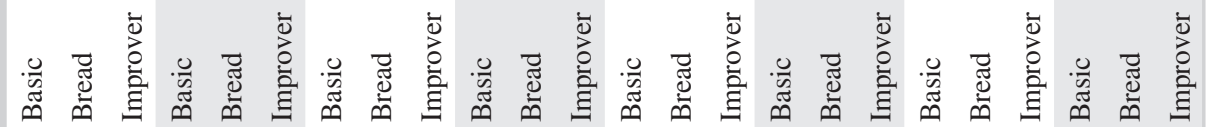

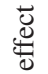

节

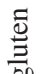

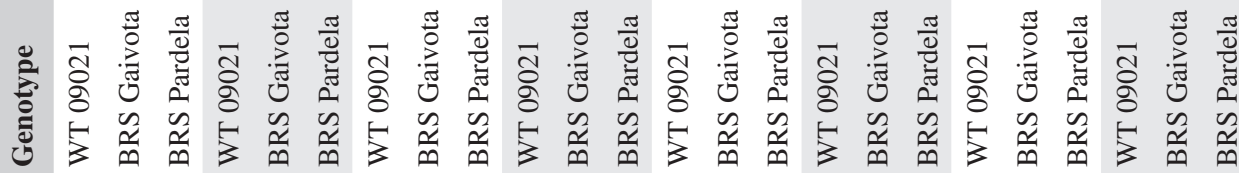

웅

일

홍

音

.
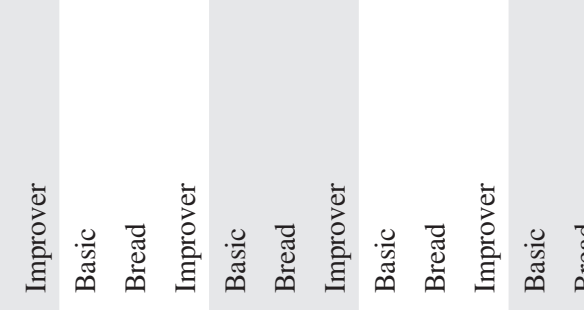

\author{
:

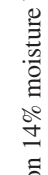

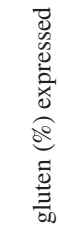


TA B L E 5 Correlation coefficient $(r)$ between rheological and protein characterization of wheat flour obtained from three wheat cultivars used in developing the gluten extraction and elastic recovery methods ${ }^{\mathrm{a}}$

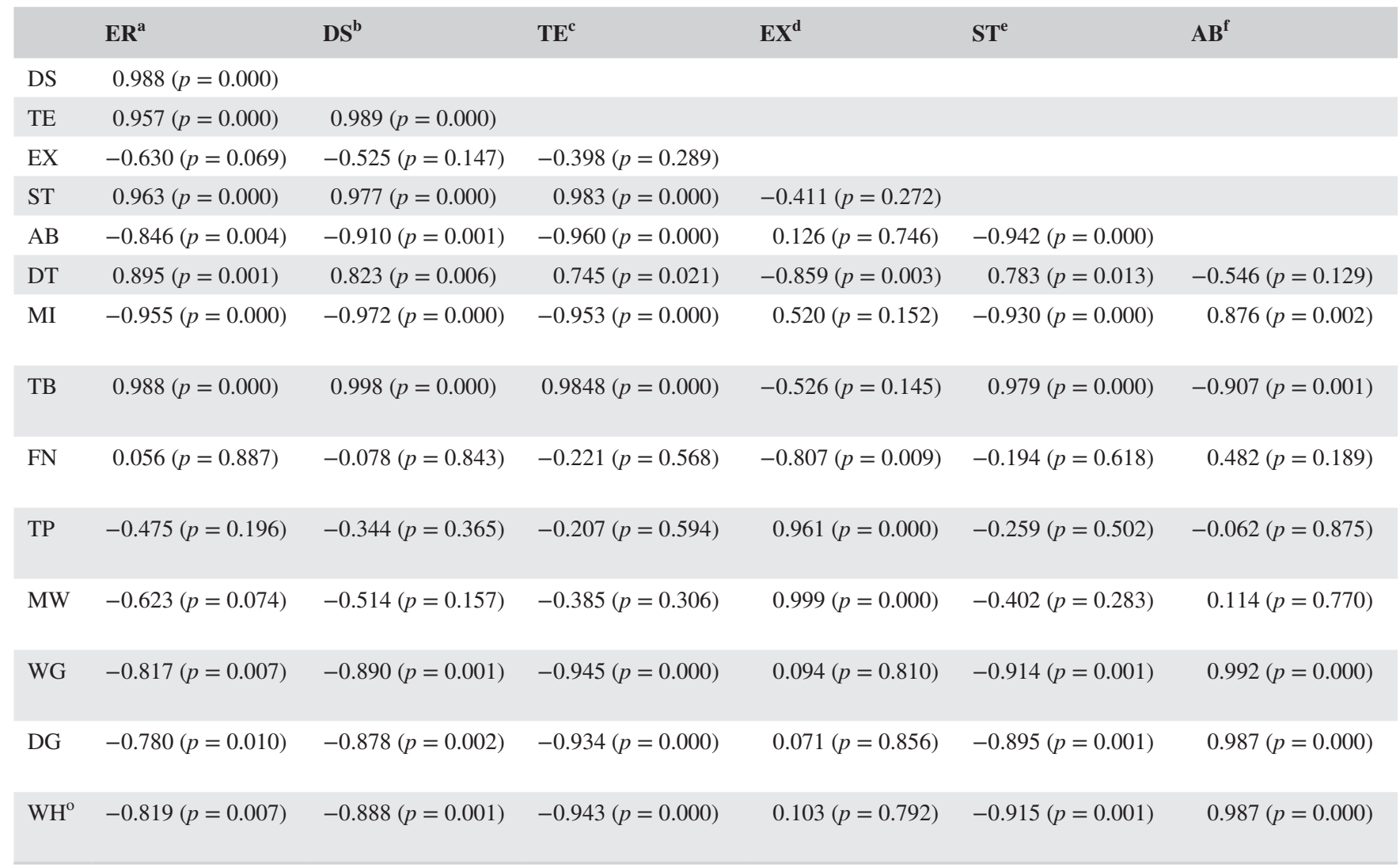

Note. Nine observations per variable.

${ }^{\mathrm{a}}$ Elastic recovery using gluten extraction method $4.4 \mathrm{ml}$ of $2 \% \mathrm{NaCl}$ solution, $20 \mathrm{~s}$ of mixing and 3 min of washing. ${ }^{\mathrm{b}}$ Dough strength. ${ }^{\mathrm{c}}$ Tenacity. ${ }^{\mathrm{d}}$ Extensibility. ${ }^{\mathrm{e}}$ Dough stability. ${ }^{\mathrm{f}}$ Water absorption. ${ }^{\mathrm{g}}$ Development time. ${ }^{\mathrm{h}}$ Mixing tolerance index. ${ }^{\mathrm{i}}$ Time to breakdown. ${ }^{\mathrm{j}}$ Falling number. ${ }^{\mathrm{k}}$ Total polymeric to total monomeric protein ratio. ${ }^{\mathrm{l}}$ Ratio of low to high molecular weight-glutenin subunits. ${ }^{\mathrm{m}}$ Wet gluten. ${ }^{\mathrm{n}}$ Dry gluten. ${ }^{\mathrm{o}}$ Water holding capacity.

wet the flour, mixing and washing times were systematically varied in a preliminary study.

From preliminary experiments, these observations were made: (a) $2 \% \mathrm{NaCl}$ solution addition for best gluten formation of $10 \mathrm{~g}$ sample was in the range of 4.0 to $4.8 \mathrm{ml}$; (b) time of mixing greater than $30 \mathrm{~s}$ resulted in a sticky dough which adhered to the sieve of the chamber, preventing the passage of the $2 \% \mathrm{NaCl}$ solution to wash the sample; and (c) washing time greater than 3 min overmixed the gluten, resulting in a sticky mass difficult to wash. The best eight conditions for gluten extraction among the 54 treatments ( 3 (genotypes) $\times 3$ $(2 \% \mathrm{NaCl}$ solution $) \times 2$ (mixing time) $\times 3$ (washing time) are reported in Table 4 . These treatments yielded acceptable performance in extracting the gluten and the separation of its elastic recovery property using the Gluten CORE method (Table 4). The treatment with the lowest CV\% for all the three Brazilian genotypes $(5.8 \%, 8.8 \%$ and $7.0 \%$ for Improver, Bread and Basic class, respectively) was selected for the validation test.

The proper amount of $\mathrm{NaCl}$ solution is essential for hydration and gluten development. Glutenin and gliadin absorb about twice their weight in water, less water results in suboptimal gluten development by reducing protein mobility, while too much water reduces gluten development by diluting the proteins and affecting their interaction. Water absorption is important for changing flow regimes in batters or flour suspensions, affecting the final product quality (Barrera et al., 2013).

The wet gluten for use in Gluten CORE test can be obtained easily and quickly (3:20 min), directly from flour, using the Glutomatic system and the test to obtain the elastic recovery takes one min. Figure 1 shows examples of compression-recovery curves for gluten extracted from each cultivar evaluated using $4.4 \mathrm{ml}$ of $2 \% \mathrm{NaCl}$ solution, $20 \mathrm{~s}$ of mixing and 3 min of washing. The gluten was shaped in the centrifuge and subjected to the described method with a compression force of $3 \mathrm{~N}$ for a hold period of $5 \mathrm{~s}$. Elastic recovery is defined as the ratio of the height at final recovery over initial height before compression, times 100 to convert to percentage. As presented in Table 4, the elastic recovery ranged from a low of $4.6 \%$ for the experimental line or Basic class cultivar (WT 09210) to $36.8 \%$ for Improver class cultivar (BRS Pardela). These values are comparable to the U.S. Soft White cv. Stephens with a degree of elasticity (elastic recovery) of 


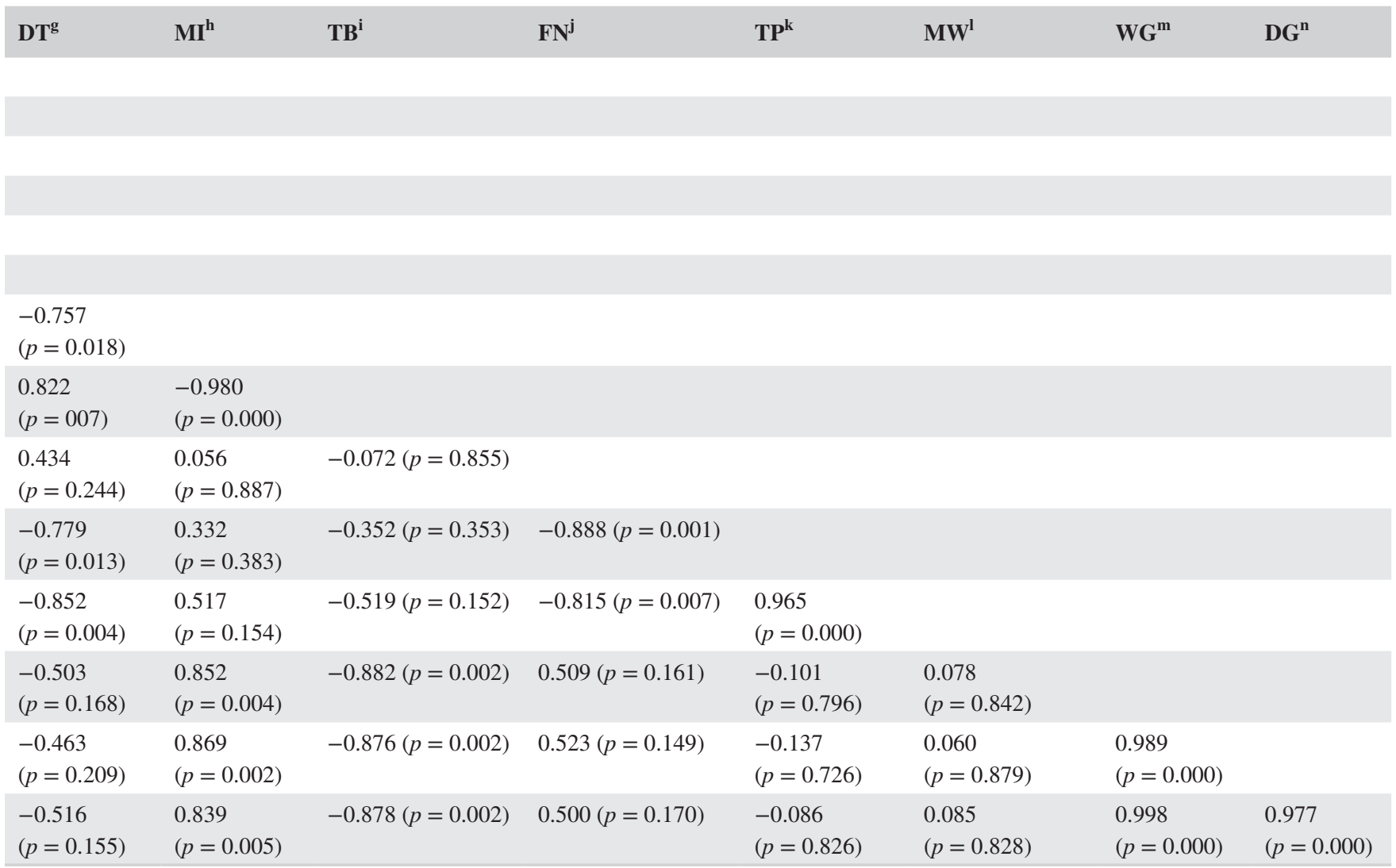

5\% and Soft Red Winter cv. Roane with 31.8\% (Chapman et al., 2012). The low percent of elastic recovery from the Basic class suggested that even a lower compression force will be advised for this class of wheat. This topic would be addressed in a follow-up study where the genotypes representing the Basic class will be weighed out by the production regions in Brazil and a larger sample size will be used. This report represents the first time that soft-textured gluten wheats from Brazil are studied comparing its rheological properties.

The cultivar containing the $5+10$ subunit pair at Glu-Dl presented the highest recovery capacity (Improver $>$ Bread $>$ Basic), which is in agreement with reports by several authors (Barak et al., 2013; He et al., 2005; Hernández-Estrada, Rayas-Duarte, \& Figueroa Cárdenas, 2017; Hernández-Estrada, Rayas-Duarte, Figueroa, \& Morales-Sánchez, 2014; Zhao et al., 2010). The Basic and Bread wheat classes presented the same allelic composition in Glu-D1 $(2+12)$; however, they have different alleles of Glu-BI $\left(17+18\right.$ and $7^{\mathrm{OE}}+8$, respectively). The overexpression of subunit $7\left(7^{\mathrm{OE}}\right)$ is known to improve the rheological characteristics of the cultivar, which explains the better elastic recovery of Bread class over Basic (Dong et al., 2010;
Eagles et al., 2002). However, the Bread class also has the wheat-rye translocation (1BL/1RS), which is detrimental to the strength of the gluten and may have ended up balancing with the overexpression of the protein.

Our results are in agreement with previous research of gluten samples presenting HMW-GS Glu-Al 1 and 2* with similar viscoelasticity behavior (Hernández-Estrada et al., 2017; Hernández-Estrada et al., 2014). According to the mentioned authors, loaf volume was higher in lines with Glu-Bl 17+18 than $7+8$ and Glu-Dl 5+10 than 2+12. In the Glu-Dl locus, good quality is especially associated with the $5+10$ pair of subunits compared with the poor quality allelic subunits $2+12$. The subunits $5+10$ also presented lower wet gluten content but higher dough stability to mixing when compared to $2+12$, in agreement with the observations in the present study (Tables 2 and 4).

Overall wet gluten, dry gluten, and water binding capacity from the samples followed the ranking Basic $>$ Bread $>$ Improver throughout all the samples and within each treatment variations (Table 4). Wet and dry gluten and water holding capacity had significant and strong negative correlation $(r=-0.876$ to $-0.943 ; p<0.001)$ 
T A B L E 6 Correlation coefficient $(r)$ between elastic recovery ${ }^{a}$ and standard empirical rheological properties used in Brazil for commercial classification of wheat obtained from validation with 44 samples from 12 wheat cultivars grown in two different locations

\begin{tabular}{|c|c|c|c|c|c|c|}
\hline Method & Parameter & Lowest value & Highest value & Average & $\begin{array}{l}\text { Correlation } \\
\text { coefficient }(r)\end{array}$ & $p$-Value \\
\hline \multirow{3}{*}{ Alveograph } & Dough strength $\left(10^{-4} \mathrm{~J}\right)$ & 149 & 368 & 209 & 0.710 & 0.000 \\
\hline & Extensibility (mm) & 65 & 217 & 118 & -0.293 & 0.053 \\
\hline & Elasticity index (\%) & 43.5 & 70.3 & 54.6 & 0.688 & 0.000 \\
\hline \multirow{3}{*}{ Farinograph } & Water absorption (\%) & 56.7 & 64.5 & 60.5 & 0.059 & 0.706 \\
\hline & $\begin{array}{l}\text { Development time } \\
\text { (min) }\end{array}$ & 4 & 16.33 & 5.6 & 0.811 & 0.000 \\
\hline & $\begin{array}{l}\text { Mixing tolerance index } \\
\text { (B.U.) }\end{array}$ & 14 & 62 & 38 & -0.420 & 0.005 \\
\hline
\end{tabular}

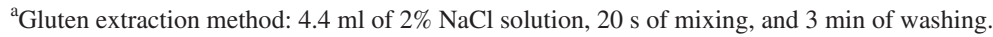

with elastic recovery, dough strength, stability, and time to breakdown (Table 5). This area needs more research since it may suggest that the water holding capacity of these genotypes is in the high tier, thus influencing gluten texture and performance. In general, wet and dry gluten are used as an estimation/guide of grain/flour protein quantity and quality when other methods are not available (Ross \& Bettge, 2009).

\section{4 | Compression-recovery test versus rheological standard methods}

Correlations of the compression-recovery test with the rheological standard methods used in Brazil are reported in Table 5 . The gluten was extracted by adding $4.4 \mathrm{ml}$ of $2 \% \mathrm{NaCl}$ solution, $20 \mathrm{~s}$ of mixing, and $3 \mathrm{~min}$ of washing. The time involved in the test starting from flour is under $5 \mathrm{~min}$ compared to minimum $20 \mathrm{~min}$ with other standard tests. There were significant and strong correlations of elastic recovery with parameters from the official methods used in Brazil to classify wheat according to their technological quality, except for falling number test (Table 5). There were also significant and strong negative correlations with wet and dry gluten and water holding capacity (Table 5). Falling number is an indication of the soundness of wheat and the values of the set of samples all were much higher than $350 \mathrm{~s}$ confirming that it was sound (Table 2). These values are in the very high end and will be interpreted as having no problems of precipitation or wet conditions at the end of the growth cycle, before harvesting.

The rheological properties of dough are critical in food manufacturing. The results of dough rheological characteristics are shown in Table 2. The significant correlation between alveograph dough strength and elastic recovery measured by Gluten CORE analyzer is understandable, since dough strength is directly related to the degree of elasticity measured by texture analysis; that is, more elastic gluten would have a greater snap back, or degree of recovery during an axial compression and relaxation test (Chapman et al., 2012).

Observing a satisfactory correlation within the proposed method (Gluten CORE) and the official methodologies used for commercial classification of wheats, 44 wheat samples composed of 12 genotypes grown in two locations in Brazil presenting different climate were used for a preliminary validation test of the method (Table 6). Medium to highly significant correlations were observed between the proposed method and the rheological standard methods used in Brazil to classify the wheat genotypes (alveograph and farinograph), with exception of falling number $(r=-0.225 ; p$-value $=0.141)$. The parameter dough strength $(r=0.710 ; p=0.000)$ and stability $(r=0.826 ; p=0.000)$, which are the actual parameters used for the commercial classification, presented satisfactory correlation with the elastic recovery properties presented by the wheat genotypes (44 samples).

More studies with an increased number of samples that possess a range of technological quality are needed to confirm the results reported here. There is also a need to evaluate a dedicated method for genotypes with the lower end of elastic recovery using the Gluten CORE. This study reports for the first time the comparison of the possible use of rheological properties of gluten in sample with a soft-type gluten with normative parameters in Brazil. Gluten elastic properties successfully separated the three classes of wheat and 
have potential to be used in breeding programs and quality control in the industry.

\section{CONCLUSIONS}

A rapid method (under $5 \mathrm{~min}$ ) for analyzing Brazilian wheat genotypes was developed using $10 \mathrm{~g}$ of flour in a Gluten CORE suitable for analysis of early generation breeding lines and quality control. The best conditions for gluten extraction and analysis were obtained by adding $4.4 \mathrm{ml}$ of $2 \% \mathrm{NaCl}$ solution to wet the flour before the mixing step, $20 \mathrm{~s}$ of mixing and 3 min of washing with $\mathrm{NaCl}$ solution (2\%). Using these settings to extract the gluten, the method was able to differentiate three commercial classes of Brazilian wheat based on their elastic recovery properties, showing a strong correlation $(r)$ with standard methods used to classify wheat according to its technological quality (dough strength $=0.988$ and dough stability $=0.963$ ). The preliminary test of validation using 44 samples, with different rheological characteristics grown in different regions of Brazil (south and southeast), presented satisfactory results when correlated $(r)$ with standard methods used in Brazil to classify wheat genotypes (alveograph dough strength and farinograph dough stability; $r=0.710$ and 0.826 , respectively), with exception of falling number. More studies are needed using a larger number of samples with different characteristics for a better understanding of wheat class separation that applies to especially soft-type genotypes.

\section{ACKNOWLEDGMENTS}

Research funded by the National Council for Scientific and Technological Development $(\mathrm{CNPq})$, Science without Borders Program (246363/2012-6), in association with MAPA (Ministry of Agriculture, Livestock and Supply), Paraná Fund UGF-SETI and CAPES (Coordination of Improvement of Higher Education Personnel)-Nanobiotechnology project (23), Oklahoma State University and U.S. Department of AgricultureNational Institute of Food and Agriculture (USDA-NIFA).

\section{ORCID}

Thiago Montagner Souza (D) https://orcid. org/0000-0002-8179-8733

Patricia Rayas-Duarte (D) https://orcid. org/0000-0003-1997-7703

\section{REFERENCES}

AACC International (1999). Approved methods of analysis, 11th ed. Method 26-10.02. Experimental Milling: Introduction, Equipment, Sample Preparation, and Tempering. Approved
November 3, 1999. Method 46-30.01. Crude Protein Combustion Method. Approved November 3, 1999. Method 54-30.02. Alveograph Method for Soft and Hard Wheat Flour. Approved November 3, 1999. Method 54-21.02. Rheological Behavior of Flour by Farinograph: Constant Flour Weight Procedure. Approved January 6, 2011. Method 38-12.02. Wet Gluten, Dry Gluten, Water-Binding Capacity, and Gluten Index. Approved November 8, 2000. Method 46-19.01. Crude Protein, Calculated from Percentage of Total Nitrogen, in Wheat and Flour. Approved November 3, 1999. Method 56-81.03. Determination of Falling Number. Approved November 3, 1999. St. Paul, MN: AACC International.

Abdelsalam, N. R. (2014). Marker assisted-selection of major traits in Egyptian bread wheat bread wheat (Triticum aestivum L.) and one wild wheat (Aegilops ventricosa Tausch). Plant Cell Biotechnology and Molecular Biology, 15, 79-86.

Barak, S., Mudgil, D., \& Khatkar, B. S. (2013). Relationship of gliadin and glutenin proteins with dough rheology, flour pasting and bread making performance of wheat varieties. LWT-Food Science and Technology, 51, 211-217. https://doi.org/10.1016/j. lwt.2012.09.011

Barrera, G. N., Bustos, M. C., Iturriaga, L., Flores, S. K., León, A. E., \& Ribotta, P. D. (2013). Effect of damaged starch on the rheological properties of wheat starch suspensions. Journal of Food Engineering, 116, 233-239. https://doi.org/10.1016/j. jfoodeng.2012.11.020

Bassoi, M. C., Riede, C. R., Campos, L. A. C., Foloni, J. S. S., Nascimento Junior, A., \& Arruda, K. M. A. (2017). Cultivares de Trigo e Triticale - Embrapa e Iapar, pp. 24-29. Londrina, Brazil: Embrapa Soja. Retrieved from https://www.embrapa.br/soja/busca-de-publicacoes/-/publicacao/1068237/ cultivares-de-trigo-e-triticale-embrapa-e-iapar

Bean, S. R., Lyne, R. K., Tilley, K. A., Chung, O. K., \& Lookhart, G. L. (1998). A rapid method for quantitation of insoluble polymeric proteins in flour. Cereal Chemistry, 75, 374-379. https://doi. org/10.1094/CCHEM.1998.75.3.374

Butow, B. J., Gale, K. R., Ikea, J., Juhasz, A., Bedö, Z., Tamas, L., \& Gianibelli, M. C. (2004). Dissemination of the highly expressed Bx7 glutenin subunit (Glu-B1al allele) in wheat as revealed by novel PCR markers and RP-HPLC. Theoretical and Applied Genetics, 109, 1525-1535. https://doi.org/10.1007/ s00122-004-1776-8

Carson, G. R., \& Edwards, N. M. (2009). Criteria of wheat and flour quality. In K. Khan, \& P. R. Shewry (Eds.), Wheat: Chemistry and technology (pp. 97-118). Saint Paul, MN: AACC.

Carver, B. F., \& Rayburn, A. L. (1995). Comparison of related wheat stocks possessing 1B or T1BL-1RS chromosomes: Grain and flour quality. Crop Science, 35, 1316-1321.

Castro, R. L., Caierão, E., Só, M., Scheeren, P. L., Guarienti, E. M., \& de Miranda, M. Z. (2016). Número ideal de amostras para classificação comercial de cultivares de trigo no Brasil. Pesquisa Agropecuária Brasileira, 51, 809-817. https://doi.org/10.1590/ S0100-204X2016000700003

Chapman, S. J., Mulvaney, S. J., Chinnaswamy, R., Rayas-Duarte, P., \& Allvin, B. (2012). Large deformation stress relaxation and compression-recovery of gluten representing different wheat classes. Journal of Cereal Science, 55, 366-372.

Costa, M. S., Scholz, M. B. S., \& Franco, C. M. L. (2013). Effect of high and low molecular weight glutenin subunits, and subunits of gliadin on physicochemical parameters of different wheat genotypes. Food 
Science and Technology (Campinas), 33(Suppl. 1), 163-170. https:// doi.org/10.1590/S0101-20612013000500024

Dong, L., Zhang, X., Liu, D., Fan, H., Sun, J., Zhang, Z., ... Wang, D. (2010). New insights into the organization, recombination, expression and functional mechanism of low molecular weight glutenin subunit genes in bread wheat. PLOS ONE, 5, e13548. https://doi. org/10.1371/journal.pone.0013548

Eagles, H. A., Hollamby, G. J., Gororo, N. N., \& Eastwood, R. F. (2002). Estimation and utilisation of glutenin gene effects from the analysis of unbalanced data from wheat breeding programs. Crop and Pasture Science, 53, 367-377. https://doi.org/10.1071/AR01074

Fu, B. X., \& Kovacs, M. I. P. (1999). Research Note: Rapid singlestep procedure for isolating total glutenin proteins of wheat flour. Journal of Cereal Science, 29, 113-116. https://doi.org/10.1006/ jcrs.1998.0225

Gupta, R. B., Khan, K., \& MacRitchie, F. (1993). Biochemical basis of flour properties in bread wheats. I. Effects of variation in the quantity and size distribution of polymeric protein. Journal of Cereal Science, 18, 23-41. https://doi.org/10.1006/jcrs.1993.1031

He, Z. H., Liu, L., Xia, X. C., Liu, J. J., \& Pena, R. J. (2005). Composition of HMW and LMW glutenin subunits and their effects on dough properties, pan bread, and noodle quality of Chinese bread wheats. Cereal Chemistry, 82, 345-350. https://doi.org/10.1094/ CC-82-0345

Hernández-Estrada, Z. J., Rayas-Duarte, P., \& Figueroa Cárdenas, J. D. D. (2017). Creep recovery of wet gluten and high-molecular-weight glutenin subunit composition: Relationship with viscoelasticity of dough and breadmaking quality of Hard Red Winter Wheat. Cereal Chemistry, 94, 223-229. https://doi.org/10.1094/ CCHEM-03-16-0049-R

Hernández-Estrada, Z. J., Rayas-Duarte, P., Figueroa, J. D. C., \& Morales-Sánchez, E. (2014). Creep recovery tests to measure the effects of wheat glutenins on doughs and the relationships to rheological and breadmaking properties. Journal of Food Engineering, 143, 62-68. https://doi.org/10.1016/j. jfoodeng.2014.06.034

Hussain, A., \& Lukow, O. M. (1994). Characterization of the 1B/1R translocation in wheat using water extractable protein concentrate. Euphytica, 78, 109-113.

Johansson, E., Malik, A. H., Hussain, A., Rasheed, F., Newson, W. R., Plivelic, T., ... Kuktaite, R. (2013). Wheat gluten polymer structures: The impact of genotype, environment, and processing on their functionality in various applications. Cereal Chemistry, 90, 367376. https://doi.org/10.1094/CCHEM-08-12-0105-FI

Khatkar, B. S., Fido, R. J., Tatham, A. S., \& Schofield, J. D. (2002). Functional properties of wheat gliadins. II. Effects on dynamic rheological properties of wheat gluten. Journal of Cereal Science, 35, 307-313. https://doi.org/10.1006/jcrs.2001.0430

Kieffer, R. (2006). The role of gluten elasticity in the baking quality of wheat. In L. Popper, W. Schäfer, \& W. Freund (Eds.), Future of flour - A compendium of flour improvement (pp. 169-178). Clenze, Germany: Verlag Agrimedia.

Larroque, O. R., Gianibelli, M. C., Batey, I. L., \& MacRitchie, F. (1997). Electrophoretic characterization of fractions collected from gluten protein extracts subjected to size-exclusion high-performance liquid chromatography. Electrophoresis, 18, 1064-1067.

Li, Z., Ren, T., Yan, B., Tan, F., Yang, M., \& Ren, Z. (2016). A mutant with expression deletion of gene Sec-1 in a 1RS.1BL line and its effect on production quality of wheat. PLoS One, 11, e0146943. https://doi.org/10.1371/journal.pone.0146943
MAPA. (2010). Ministério da Agricultura, Pecuária e Abastecimento. Instrução Normativa ${ }^{\circ}$ 38, de 30 de novembro de 2010. Regulamento técnico do trigo. Diário Oficial [da] República Federativa do Brasil, Brasília, seção 1, n. 29, p. 2, 1 dez. Retrieved from http://www. codapar.pr.gov.br/arquivos/File/pdf/TrigoInstrucaoNormativa3810. pdf. Accessed on 26 April 2017.

Marchetti, L., Cardós, M., Campaña, L., \& Ferrero, C. (2012). Effect of glutens of different quality on dough characteristics and breadmaking performance. LWT-Food Science and Technology, 46, 224-231. https://doi.org/10.1016/j.lwt.2011.10.002

Pagani, M. A., Marti, A., \& Bottega, G. (2014). Wheat milling and flour quality evaluation. In W. Zhou, \& Y. H. Hui (Eds.), Bakery products science and technology (pp. 17-53). Ames, IA: Blackwell Publishing.

Panozzo, J. F., \& Eagles, H. A. (2000). Cultivar and environmental effects on quality characters in wheat. II. Protein. Crop and Pasture Science, 51, 629-636. https://doi.org/10.1071/AR99137

Payne, P. I., \& Lawrence, C. J. (1983). Catalogue of alleles for the complex gene loci, Glu-B1 and Glu-D1 which code for high molecular weight subunits of glutenin in hexaploid wheat. Cereal Research Communications, 11, 29-35.

Payne, P. I., Nightingale, M. A., Krattiger, A. F., \& Holt, L. M. (1987). The relationship between HMW glutenin subunit composition and the bread-making quality of British-grown wheat varieties. Journal of the Science of Food and Agriculture, 40, 51-65. https://doi. org/10.1002/jsfa.2740400108

Ross, A. S., \& Bettge, A. D. (2009). Passing the test on wheat end-use quality. In B. F. Carver (Ed.) Wheat: Science and trade (pp. 455494). Ames, IA: Wiley-Blackwell.

Tabibzadeh, N., Karimzadeh, G., \& Naghavi, M. R. (2013). Distribution of 1AL.1RS and 1BL.1RS wheat-rye translocations in Iranian wheat, using PCR based markers and SDS PAGE. Cereal Research Communications, 41, 1-10. https://doi. org/10.1556/CRC.2013.0023

Torres, G. A. M., de Miranda, M. Z., Nicolau, M., Consoli, L., Costa, L. F. M. M., \& Tomazin, T. (2008). Estudos preliminares da associação de gluteninas de alto peso molecular e parâmetros de qualidade tecnológica de trigo. In Embrapa Trigo. Documentos online 101 (pp. 3). Passo Fundo, Brazil: Embrapa-Trigo. Retrieved from https://ainfo.cnptia.embrapa.br/digital/bitstream/CNPT-2010/40720/1/p-do101.pdf

US Wheat Associates (2017). 2017 Crop Quality Report. (pp. 14). Arlington, VA: US Wheat Associates. Retrieved from http:// www.uswheat.org/cropQuality/doc/4DB84BAFA206D2F9852581C2006F0C4D/\$File/cqr2017-en.pdf?OpenElement\#

Veraverbeke, W. S., \& Delcour, J. A. (2002). Wheat protein composition and properties of wheat glutenin in relation to breadmaking functionality. Critical Reviews in Food Science and Nutrition, 42, 179-208. https://doi.org/10.1080/10408690290825510

Waga, J., Zientarski, J., Szaleniec, M., Obtulowicz, K., Dyga, W., \& Skoczowski, A. (2013). Null alleles in gliadin coding loci and wheat allergenic properties. American Journal of Plant Sciences, 4, $160-168$.

Wieser, H. (2007). Chemistry of gluten proteins. Food Microbiology, 24, 115-119. https://doi.org/10.1016/j.fm.2006.07.004

Wieser, H., \& Kieffer, R. (2001). Correlations of the amount of gluten protein types to the technological properties of wheat flours determined on a micro-scale. Journal of Cereal Science, 34, 19-27. https://doi.org/10.1006/jcrs.2000.0385

Wrigley, C. W., Bekes, F., \& Bushuk, W. (2006). Gluten: A balance of gliadin and glutenin. In C. W. Wrigley, F. Bekes, \& W. Bushuk 
(Eds.), Gliadin and glutenin. The unique balance of wheat quality (pp. 3-32). St. Paul, MN: AACC International Press.

Zhao, D., Mulvaney, S., Chinnaswamy, R., Rayas-Duarte, P., Allvin, B., \& Wang, M. (2010). Elastic properties of gluten representing different wheat classes. Journal of Cereal Science, 52, 432-437.

Zhu, J., \& Khan, K. (2001). Effects of genotype and environment on glutenin polymers and breadmaking quality. Cereal Chemistry, 78, 125-130. https://doi.org/10.1094/CCHEM.2001.78.2.125
How to cite this article: Montagner Souza T, de Miranda MZ, Mateus Prando A, Tilley M, Payton ME, Rayas-Duarte P. Gluten viscoelasticity: Rapid method for classification of soft-like wheat genotypes. Cereal Chem. 2019;96:167-181. https://doi.org/10.1002/ cche. 10128 